\title{
A STUDY ON THE POSSIBLE EFFECT OF TWO CRAYFISH SPECIES ON EPILITHIC ALGAE IN A MOUNTAIN STREAM FROM CENTRAL SPAIN
}

\author{
J.A. ARCE (1), F. ALONSO (1), E. RICO (2), A. CAMACHO (3)
}

(1) Centro de Investigación Agraria de Albaladejito, Junta de Comunidades de Castilla-La Mancha. Ctra. Toledo-Cuenca, Km 174. E-16194 Cuenca, Spain. E-Mail: abecario@jccm.es; falonso@jccm.es

(2) Dpto. Ecología, Universidad Autónoma de Madrid, E-28049 Madrid, Spain. E-Mail: eugenio.rico@uam.es

(3) Instituto Cavanilles de Biodiversidad y Biología Evolutiva y Dpto. Microbiología y Ecología, Edificio de Investigación, Campus de Burjassot, Universitat de València, E-46100 Burjassot, Valencia, Spain. E-Mail: antonio.camacho@uv.es

Reçu le 2 juin 2005

Accepté le 28 novembre 2005

Received June 2, 2005

Accepted November 28, 2005

\begin{abstract}
The effects on epilithic algae of increasing densities of two crayfish species, Austropotamobius italicus and Pacifastacus leniusculus, the latter recently introduced in Spain, have been monitored using riverine enclosures, within a large experimental study on crayfish-macrobenthos interactions in a mountain stream. A 3-month test was carried out for each species using crayfish densities comprising between 0-5 individuals $/ \mathrm{m}^{2} \mathrm{kept}$ in $1-\mathrm{m}^{2}$ enclosures. Epilithon was sampled periodically within the enclosures and chlorophyll $a, b$ and $c$ were measured by spectrophotometry. Neither statistically significant positive nor negative effects were observed on algal abundance (Chl concentrations) during the experiments. Both species showed similar responses with time, with no significantly marked trends.
\end{abstract}

Key-words: Austropotamobius italicus, Pacifastacus leniusculus, chlorophylls, epilithon.

\section{ÉTUDE DE L'IMPACT DEUX ESPÈCES D'ÉCREVISSES SUR LES ALGUES ÉPILITHIQUES DANS UNE RIVIĖRE DE MONTAGNE DANS LE CENTRE DE L'ESPAGNE}

\section{RÉSUMÉ}

Dans le cadre d'une étude expérimentale plus large sur les interactions entre les écrevisses et le macrobenthos dans une rivière de montagne, nous avons étudié l'impact sur les algues épilithiques de densités croissantes de deux espèces d'écrevisses, Austropotamobius italicus et Pacifastacus leniusculus, cette dernière ayant été récemment introduite. A cette fin, une expérimentation de 3 mois a été mise en place. Des écrevisses ont été placées dans des limnocages de $1 \mathrm{~m}^{2}$, avec des densités de 0 à 5 spécimens $/ \mathrm{m}^{2}$, et en séparant les espèces. Des prélèvements périodiques d'épilithon ont été réalisés afin 
d'analyser les teneurs en chlorophylles $a, b$ et $c$. II n'a pas été mis en évidence d'impact statistiquement significatif des écrevisses sur l'abondance des algues épilithiques (concentrations en Chl). Les deux espèces ont suivi une évolution similaire pendant toute la durée de l'expérience.

Mots-clés: Austropotamobius italicus, Pacifastacus leniusculus, chlorophylles, épilithon.

\section{INTRODUCTION}

Studies exploring crayfish diet have increased since the late 1970s, mainly in North America (AVAULT, 1973; RIVAS et al., 1978; ROMAIRE et al., 1978). However, most of these were related to an economic perspective based on production, rather than considering any truly ecological focus. Years later the amount of experiments investigating natural diet of crayfish increased, with important contributions from European workers. Most of them have paid attention to specific organisms, in an attempt to assess the intensity of possible direct impacts on their established populations, such as those on freshwater invertebrates (WARNER et al., 1995; PERRY et al., 1997; WARNER, 1997) and macrophytes (MATTHEWS et al., 1993; ILHÉU and BERNARDO, 1995), either based on microcosm experiments (REYNOLDS, 1978; WARNER and GREEN, 1995) or on gut content analyses (WESTMAN et al., 1986; ILHÉU and BERNARDO, 1993; RABENI et al., 1995). These kinds of tests may face different issues about crayfish feeding preferences, confirming in many cases the usual omnivory displayed by crayfish, resulting from shifts depending on factors such as the age, and availability or energetic value of potential food sources (GAUDIOSO et al., 1987; ILHÉU and BERNARDO, 1995; RABENI et al., 1995). These works essentially reinforce our knowledge on the autoecology of certain species within the biotic communities where they dwell. With this starting point, several approaches to the trophic ecology in natural environments have been carried out, with the aim of elucidating the functional role of crayfish in freshwater ecosystems. Consequently, their ecological position has been debated at length, emphasizing their possible controlling function by predation in lenitic and lotic ecosystems as well as a basic resource for larger fauna (SLATER and RAYNER, 1993).

Modern studies, however, are progressively tending to the search for interactions among all community elements within those ecosystems they inhabit, and specially on the cascade effects of possible key species, which have focused either on indigenous (HESSEN et al., 1993; MATTHEWS et al., 1993) or invasive crayfish species (APPELBERG and ODELSTROM, 1988; ILHÉU and BERNARDO, 1993; NYSTRÖM and ABJÖRNSSON, 2000; NYSTRÖM et al., 2001) trying to predict non-desirable impacts over potential spreading areas.

Epilithon, microalgae growing on stones, is a basic component of stream food webs, representing the main photosynthetic element in those habitats where macrophytes are scarce, as currently occurs in mountain streams. It comprises that part of periphyton (every microorganism colonising almost any submerged substratum) growing specifically on rock surfaces (LOWE and LALIBERTE, 1996). This functional group of organisms has also been the target of different assessments considering diversity and biomass parameters. While a large part of such studies have been performed in short-term laboratory assays, we present an approach in which the interactions between crayfish (as well as other macroinvertebrates) and epilithon were monitored under natural conditions for three months. Although not displayed here, work is in progress to study the interactions of crayfish with other organisms within the experimental stream and those results will be available in further manuscripts. This would include both the possible effect of crayfish on the structure of the macroinvertebrate community, as well as the time-course of the abundance of each algal species during the experiments, knowledge of which would allow 
sounder evaluation of the effect of crayfish on community structure in small Mediterranean streams. In this work we use a preliminary approach by means of aggregate variables such as photosynthetic pigment abundance as a quantitative parameter describing the evolution of the overall abundance of epilithic algae under different crayfish abundances.

\section{MATERIAL AND METHODS}

The studied stream is located in the province of Cuenca (Central Spain), within the Iberic Range, at 1,145 $\mathrm{m}$ a.s.l. (Figure 1). The experiments were conducted in a karstic mountain stream belonging to the Júcar River basin, which drains easterly to the Mediterranean Sea. The main characteristics of the stream are summarized (Table I).

Two 12-week enclosure-experiments were carried out in 2004, each with a different species of crayfish: Pacifastacus leniusculus (Dana), with experiments performed in summer, and Austropotamobius italicus (Faxon), whose experiments were conducted during autumn. Each experiment consisted of four crayfish density treatments, with 1, 3 and 5 individuals $/ \mathrm{m}^{2}$ as well as a control with no crayfish, covering the range of densities found in natural conditions. For this purpose, $15-1 \mathrm{~m}^{2}$ wire cages were placed on the streambed and filled with a layer of $c a .10 \mathrm{~cm}$ of natural substrate three months before the beginning of each experiment. Cages were kept in place by substrate weight and auxiliary anchoring. Four replicates were carried out for every crayfish density treatment and three replicates for controls. Cages were completely covered with a $13 \mathrm{~mm}$ metallic mesh, which allowed free colonization of algal and macrobenthic populations while preventing most twigs and leaves from riparian vegetation from falling inside. Only male crayfish were employed in the experiments in order to avoid the risk of non-desired populations being established by escapees, and to eliminate sex bias. Individuals with similar sizes were selected (Table II). Crayfish survivorship was controlled every 3-4 days, dead ones being removed and substituted with similarly acclimatized individuals.

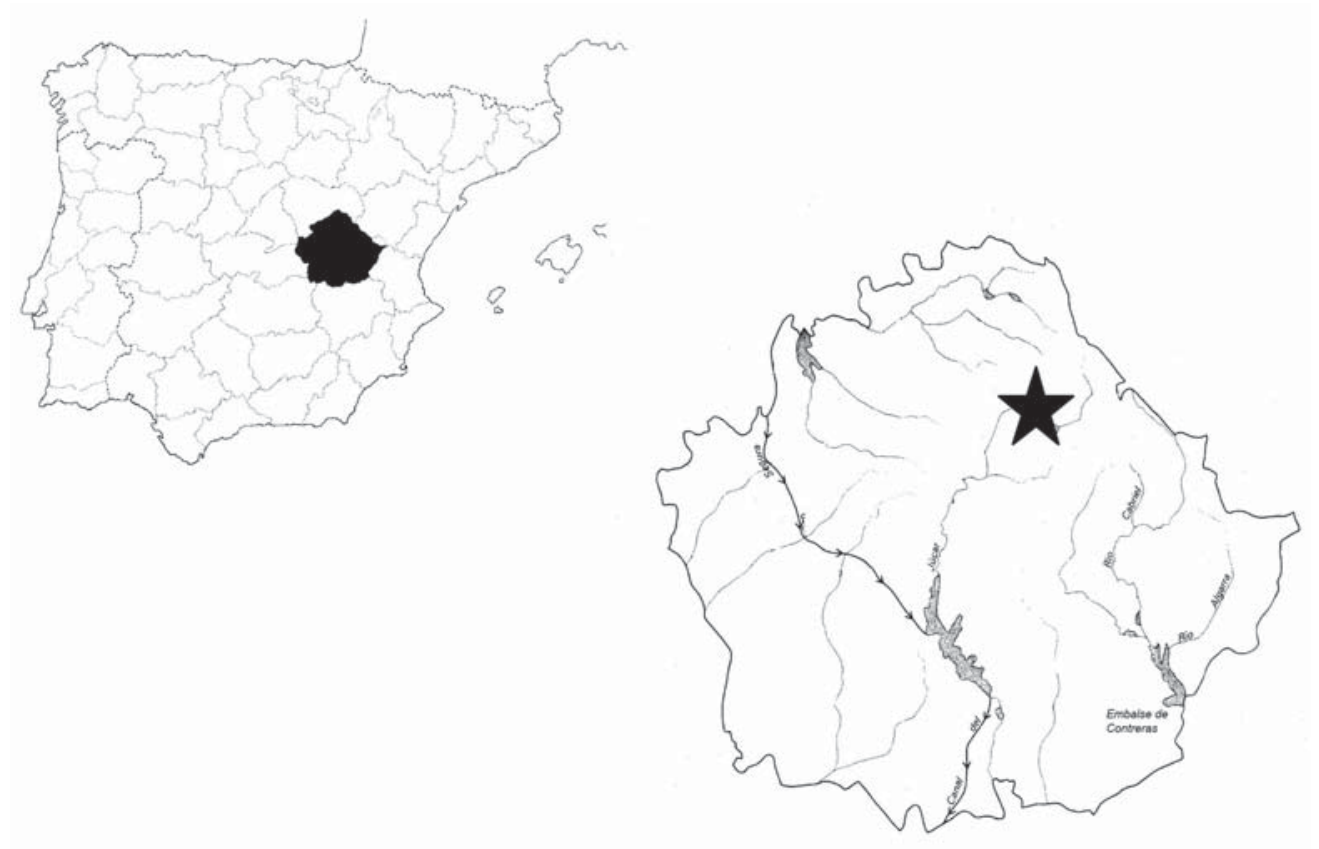

Figure 1

Study site within the province of Cuenca.

\section{Figure 1}

Aire de l'étude dans la province de Cuenca. 


\section{Table I}

Main physicochemical parameters from study site in the province of Cuenca. Measures were taken every two weeks during each experiment.

\section{Tableau I}

Principales caractéristiques physico-chimiques dans l'aire d'étude, province de Cuenca. Les mesures ont été réalisées toutes les deux semaines pour chaque expérimentation.

\begin{tabular}{|l|l|}
\hline Drainage order & 1 \\
\hline Mean flow & $500 \mathrm{l} / \mathrm{s}$ \\
\hline Depth & $15-25 \mathrm{~cm}$ \\
\hline $\mathrm{PH}$ & $7-7.5$ \\
\hline Conductivity & $508-513 \mu \mathrm{S} / \mathrm{cm}$ \\
\hline Dissolved oxygen & $9-10 \mathrm{mg} / \mathrm{l}$ \\
\hline Temperature & $10-10.5^{\circ} \mathrm{C}$ \\
\hline
\end{tabular}

Table II

Sizes of individuals employed during the experiments within the study site. Values are means \pm SD.

\section{Tableau II}

Tailles des écrevisses utilisées au cours des expérimentations dans l'aire d'étude. Les valeurs sont les moyennes \pm SD.

\begin{tabular}{|l|c|c|}
\hline & A. italicus & P. leniusculus \\
\hline Carapace length $(\mathrm{mm})$ & $41.93 \pm 2.19$ & $45.13 \pm 1.57$ \\
\hline Weight $(\mathrm{g})$ & $24.61 \pm 5.39$ & $24.53 \pm 3.16$ \\
\hline
\end{tabular}

Every two weeks a sample of epilithon was taken from each cage. Each sample was obtained by scraping on site with a toothbrush the face exposed to current of 56 completely submerged stones. The slurries were flushed into plastic jars, placed on ice in the dark and transported to the laboratory until processing. To determine the sampled area in each stone, the aluminium foil method was employed (STEINMAN and LAMBERTI, 1996). Every sample was divided in two batches, one was preserved in $4 \%$ formaldehyde for algal identification under an optical microscope $(\times 400, \times 1,000)$, and the other was used in pigment analysis in order to calculate chlorophyll concentrations. For the latter, collected volumes were vacuum-filtered employing GF/F glass microfibre filters, then kept in $90 \%$ acetone for 24 hour in a refrigerator to complete pigment extraction (STEINMAN and LAMBERTI, 1996). After centrifugation, spectrophotometric analysis of each sample was carried with a BECKMAN DU-640 spectrophotometer, measuring absorbances at 665, 645 and $630 \mathrm{~nm}$. Concentrations of chlorophyll $a, b$ and $c\left(\mu \mathrm{g} \mathrm{Chl} / \mathrm{m}^{2}\right)$ were carried out using formulae proposed by PARSONS and STRICKLAND (MARGALEF, 1983). The search for three different kinds of chlorophylls is aimed at establishing correspondences between their concentrations and the distinct taxonomic algal groups responsible for each one (LOWE and LALIBERTE, 1996), mainly chlorophyll $b$ for filamentous chlorophytes and chlorophyll $c$ for diatoms (CAMACHO and DE WIT, 2003). 
Fixed effects ANOVA tests were performed individually for both crayfish species, once square root transformation of chlorophyll data was performed in order to obtain normalized data. When appropriate, LSD tests were also employed for a posteriori specific contrasts.

\section{RESULTS}

As observed in Table III, $p$-values from ANOVA tests comparing evolution of chlorophyll a concentrations showed no existence of statistical differences between treatments for each assessed species. Both chlorophyll $b$ and $c$ patterns showed no clear trends among treatments during the development of our experiments, in accordance with those shown by chlorophyll a concentrations, thus indicating the lack of statistically significant marked positive or negative effects of both $A$. italicus and $P$. leniusculus on epilithon during the experiments (Table III). Despite chlorophyll data transformation high intragroupal variation occurred, which contributes to actual $p$-values being far from ordinary significance level $(p=0.05)$.

For both crayfish species, each of the three types of chlorophyll analysed kept the same proportions among treatments when considering every sampling time individually (Figure 2), indicating that their relative ratios stayed quite stable within the epilithic assemblages during the experiments. Data in the graphs is expressed as the square root of chlorophyll $\left(\mu \mathrm{g} / \mathrm{m}^{2}\right)$; consequently, proportions between concentrations of chlorophyll a, $b$ and $c$ are relative in that figure.

Results show highest concentrations of chlorophyll $a$, followed by those corresponding to chlorophyll $b$, and lowest levels for chlorophyll $c$. This is in consonance with contribution from each algal type, given that chlorophyll a occurs in all groups of epilithon observed while chlorophyll $b$ and $c$ are only produced by specific groups, i.e. green algae and diatoms.

With reference to epilithon diversity, preliminary microscopic examination of some random selected samples allowed us to determine which are the main taxa forming the epilithon assemblage, although further detailed study on the abundance of each taxa will be performed. More than 20 taxa were identified. Up to 17 diatom taxa were differentiated, 13 to the genus level and 4 to the species level. Diatoms were the dominant taxa among microalgae found in our samples. This dominance not only occurs at a qualitative level, but also from a quantitative point of view, since semi-

\section{Table III}

Results of ANOVA tests from comparisons of distinct chlorophyll concentrations between treatments during the 12-week enclosure experiments within the study site.

\section{Tableau III}

Résultats des tests ANOVA pour les différentes concentrations en chlorophylle pendant les expérimentations en cage pendant 12 semaines dans le site d'étude.

\begin{tabular}{|l|c|c|c|}
\hline & Chl $a$ & Chl $b$ & Chl $c$ \\
\hline A. italicus & $\mathrm{p}=0.7075$ & $\mathrm{p}=0.2627$ & $\mathrm{p}=0.1150$ \\
\hline P. leniusculus & $\mathrm{p}=0.4640$ & $\mathrm{p}=0.5899$ & $\mathrm{p}=0.7391$ \\
\hline
\end{tabular}



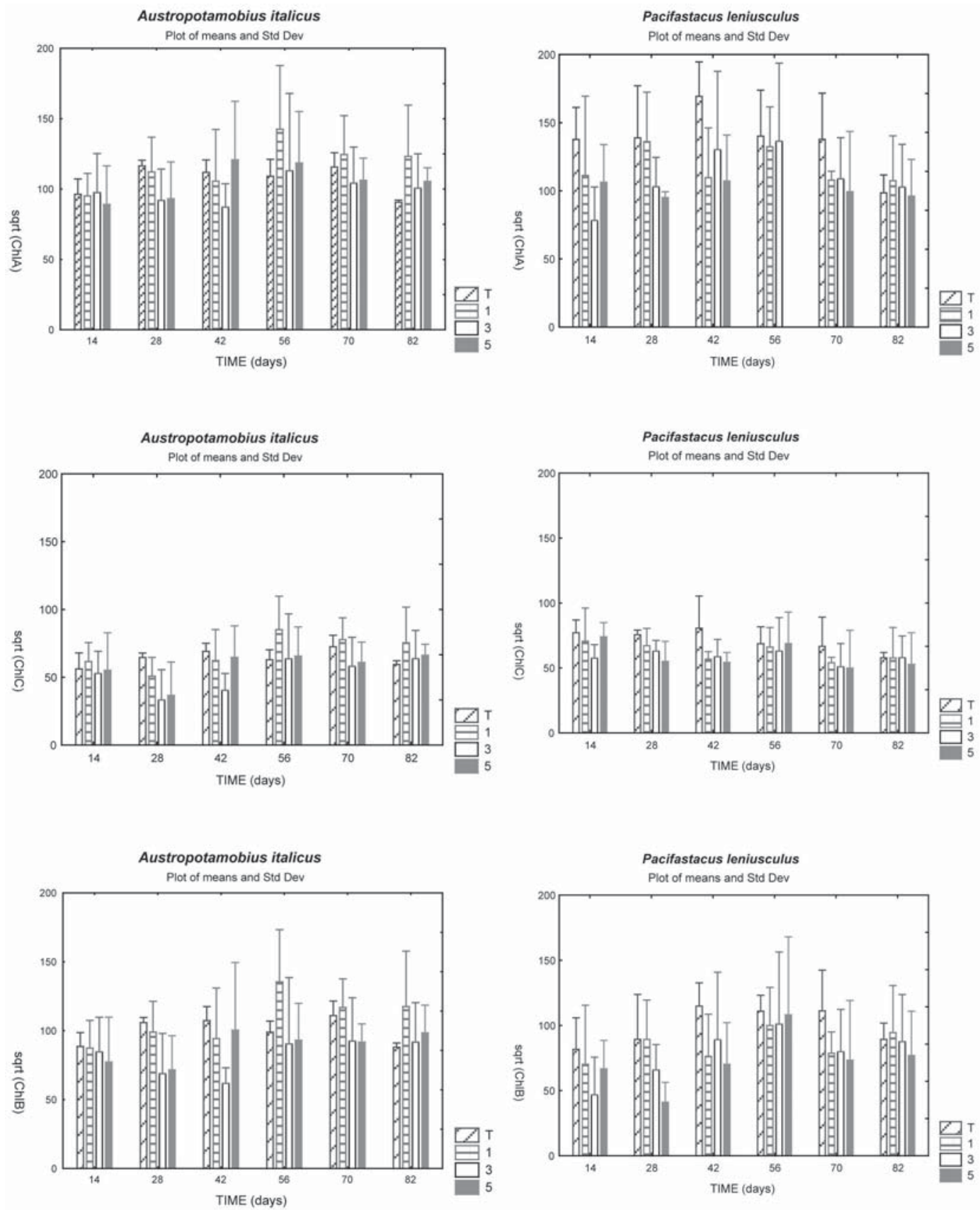

Figure 2

Averages and standard deviations patterns of distinct chlorophyll concentrations for crayfish experiments carried in the study site.

Figure 2

Évolution dans le temps des valeurs moyennes et des écarts-type des concentrations en chlorophylles pour les différentes densités d'écrevisses installées sur le site.

quantitative examination showed that diatoms were the most abundant group by far. In addition, at least two filamentous cyanobacterial taxa and four different chlorophytes were present. 


\section{DISCUSSION}

In our experiments, the evolution of chlorophyll a values did not show definite patterns in either of the crayfish species examined, indicating a lack of global effects of crayfish abundance on the total amount of epilithon. This even appeared in the highest density treatments, and could be mainly explained either by the lack of direct effects (e.g. significant epilithon consumption by crayfishes) or by the compensation of indirect effects (effect of crayfish by predation on epilithon consumers). Stimulation of algal growth through nutrient release from crayfish excretion, although possible, does not seem to occur.

Whilst it is well known that crayfish can consume algae, their impact on benthic algae biomass is less predictable than effects caused to macrophytes (NYSTRÖM, 2002). Some studies of interactions between crayfish and natural macrophyte communities show negative effects of crayfish on the latter mainly through direct consumption (BROWN et al., 1990; WARNER and GREEN, 1995). This is particularly well known for Chara species (MATTHEWS et al., 1993; SAFFRAN and BARTON, 1993; GELWICK, 2000). This is linked to the widespread idea about crayfish finding aquatic plants as a natural resource easy to access and handle whenever they are commonly available in their habitats, thus optimizing the costs-benefits ratio, even to the detriment of other trophic resources like fish or invertebrates (BUDD et al., 1978; ILHÉU and BERNARDO, 1993). Furthermore, macrophytes might be the only food resource for crayfish in some areas, even considering their omnivorous condition (GOTTSTEIN et al., 1999). Taking this aspect into account we should consider the possibility of crayfish taking advantage of distinct kinds of algae as an equally important source of food. Regarding this subject, GAUDIOSO et al. (1987) found that while adult Austropotamobius pallipes individuals mainly fed on macrophytes, smaller crayfish preferred microalgae. In addition, studies based on different crayfish species, mainly following gut contents analysis, yield strong evidence of crayfish grazing on important amounts of microalgae such as filamentous algae and diatoms (SAFFRAN and BARTON, 1993; CHARLEBOIS and LAMBERTI, 1996; WHITLEDGE and RABENI, 1997), the dominant taxa in our experimental enclosures. The distinct roles that may be played by both microalgae and macrophytes derive from their physical structure and physiognomy. For instance, filamentous algae digestibility is higher than that of most macrophytes, given their greater richness in proteins and low fibre content (ILHÉU and BERNARDO, 1995; FRANCE, 1996), which might explain an active and preferential consumption of microalgae in relation to macrophytes (ILHÉU and BERNARDO, 1995; RABENI et al., 1995; WHITLEDGE and RABENI, 1997). On the other hand, diatoms are probably eaten by crayfish in a non-selective (microphagic) way, either by filtration processes or accidentally mixed with the sediment in which they dwell (HESSEN and SKURDAL, 1986; O'BRIEN, 1995). A third ingesting path could be their presence from the gut of scraper insects previously ingested by crayfish (GUAN and WILES, 1998).

The results of most studies seem to suggest that crayfish have negative effects on macroscopic algae, while their direct impact on microalgae is probably less intense (NYSTRÖM et al., 1999). This agrees with the lack of significant effects that we found in our experiments, given that all our epilithon corresponds to microalgae. Experiments conducted by GOTTSTEIN et al. (1999) in a stream with similar features also did not yield any correlation between chlorophyll a values and crayfish densities, although in that case the study was centred on planktonic microalgae, contrary to our study on epilithic microalgae. Contrastingly, a number of works, mostly performed with Orconectes species, predicted negative effects on periphyton, and explained these reductions in the substrate coverage and biomass of primary producers by a direct consumption by crayfish either of unicellular (HART, 1992; KELLER and RUMAN, 1998) or filamentous algae (FRANCE and WELBOURN, 1992; CREED, 1994; LUTTENTON et al., 1998); although it has been argued (LUTTENTON et al., 1998) that crayfish are not good grazers on these organisms, especially on diatoms. 
Other authors have pointed out the relevance of an indirect effect resulting from the action of crayfish reducing colonisable surface to algae through consumption of macrophytes, which in turn serve as colonisable substrate for periphyton (LODGE et al., 1994), although in these cases they refer to epiphytic algae and not to those assessed in the present study, which dwell on rocky substrates because of the absence of macrophytes in our enclosures. Another indirect effect proposed by TURNER et al. (2000) and by APPELBERG and ODELSTROM (1988) considers the ability displayed by phytophagous invertebrates to group together in microhabitats (refuges), avoiding predation from crayfish. Although this behaviour has been qualitatively observed in our experiments for some groups of caddisflies and elmids, further detailed quantification, currently being performed, is necessary in our case to test such issues.

In contrast to the above-mentioned effects, some authors describe positive cascade effects of crayfish on algal assemblages. Direct consumption by crayfish could lower herbivorous numbers, (WEBER and LODGE, 1990; LODGE et al., 1994; NYSTRÖM et al., 1999; NYSTRÖM and ABJÖRNSSON, 2000; NYSTRÖM et al., 2001), and in turn release some grazing pressure over epilithon. This effect would be more evident in areas, like our study site, with few macrophytes, where feeding activity of phytophagous macroinvertebrates concentrates on epilithon. Few works have studied the interaction between signal crayfish and algae, and not any has been done so with $A$. italicus. Several chlorophyll-a studies carried out in Swedish freshwater systems revealed positive impacts of signal crayfish on microalgae numbers, associated to the consumption of snails (NYSTRÖM et al., 1999; NYSTRÖM et al., 2001) or tadpoles (NYSTRÖM and ABJÖRNSSON, 2000) and a subsequent reduction of grazing pressure. Up to date, snail grazers' densities (mainly Hydrobiidae) in our study site have not been resolved. Nonetheless, our report may be considered as an initial trophic study involving crayfishepilithon interactions in Spain, until now overshadowed by the preferential attention paid to the interactions of these animals with macrophytes.

However, it is remarkable that positive impacts are generally shown in chlorophyll analyses while negative or neutral effects can be observed from microscopic biomass estimations. A valid argument to explain this fact would relate to the locomotion and prospecting activities of crayfish which, by removing the detritus covering algal biofilms, would recycle an additional pool of nutrients at the same time as removing senescent algal cells (mostly non-productive), increasing in this way the amount of chlorophyll content per cell, with higher content for actively growing cells, but without significantly changing their biomass although such senescent algae (with lower chlorophyll content) were also usually included in biomass quantification (CREED, 1994; CHARLEBOIS and LAMBERTI, 1996).

In our studies, the relatively low number of replicates (4) conducted for each treatment (crayfish density), may partly explain our lack of significant responses because of increased intragroupal variation coefficients. This is an actual limitation attached to our application of methodologies based on enclosures given the large amount of time needed for the experiments and sample handling, as occurred in our or other similar studies (CHARLEBOIS and LAMBERTI, 1996; USIO and TOWNSEND, 2002). Additionally, in our case while it would have been better to carry out the experiments on A. italicus and $P$. leniusculus individuals simultaneously, a real possibility of transmission of diseases between both species, together with time and space limitations, advised us not to put this idea in practice. As a consequence we tried to minimise these undesirable effects by setting a series of controls for each block of experiments.

In brief, our results suggest that natural densities of both crayfish species assayed would not directly affect the net amount of epilithon. This could be explained if in this kind of Mediterranean mountain stream crayfish manage to turn to the use of alternative food sources other than algae, such as invertebrates, depending on their availability and ease 
of handling for crayfish. A correct procedure to contrast all mentioned effects needs to be completed by an assessment of changes in the qualitative and quantitative composition of macroinvertebrate benthic assemblages, which we are currently performing. Additionally, aquaria experiments as well as gut contents analyses, also under preparation, would contribute to improve our knowledge about these biotic interactions in the studied systems.

\section{ACKNOWLEDGEMENTS}

We wish to thank Orencio Sánchez for his help in field work, and the staff from Rincón de Uña hatchery for allowing us to carry out the experiments. A. italicus individuals were provided by Rillo de Gallo crayfish farm. J.A. Arce was supported with a grant from the Instituto Nacional de Investigación y Tecnología Agraria y Alimentaria (INIA). Funding for this work was provided by Project SIA 03-218-RN-32.

\section{REFERENCES}

APPELBERG M., ODELSTRÖM T., 1988. Interaction between European perch (Perca fluviatilis) and juvenile Pacifastacus leniusculus (Dana) in a pond experiment. Freshwater Crayfish, 7, 37-45.

AVAULT J.W., 1973. Crayfish farming in the United States. Freshwater Crayfish, 1, 239250.

BROWN P.B., TAZIK P., HOOE M.L., BLYTHE W.G., 1990. Consumption and apparent dry matter digestibility of aquatic macrophytes by male and female crayfish (Orconectes virilis). Aquaculture, 89, 55-64.

BUDD T.W., LEWIS J.C., TRACEY M.L., 1978. The filter-feeding apparatus in crayfish. Can. J. Zool., 56, 695-707.

CAMACHO A., DE WIT R., 2003. Effect of nitrogen and phosphorus additions on a benthic microbial mat from a hypersaline lake. Aquat. Microb. Ecol., 32, 261-273.

CHARLEBOIS P.M., LAMBERTI G.A., 1996. Invading crayfish in a Michigan stream: direct and indirect effects on periphyton and macroinvertebrates. J. North. Am. Benthol. Soc., 15(4), 551-563.

CREED R.P., 1994. Direct and indirect effect of crayfish grazing in a stream community. Ecology, 75, 2091-2103.

FRANCE R.L., 1996. Ontogenetic shift in crayfish ${ }^{13} \mathrm{C}$ as a measure of land water ecotonal coupling. Oecologia, 107, 239-242

FRANCE R.L., WELBOURN P.M., 1992. Influence of lake pH and macrograzers on the distribution and abundance of nuisance metaphytic algae in Ontario, Canada. Can. J. Fish. Aquat. Sci., 49, 185-195.

GAUDIOSO V.R., CELADA J.D., CARRAL J., RODRÍGUEZ P.L., 1987. El cangrejo de río en León. Universidad de León, 90 p.

GELWICK F.P., 2000. Grazer identity changes the spatial distribution of cascading trophic effects in stream pools. Oecologia, 125, 573-583.

GOTTSTEIN S., KEROVEC M., MAGUIRE I., BUKVIC I., 1999. Ecological notes on Austropotamobius pallipes italicus (Faxon, 1914) (Decapoda, Astacidae) in a karstic spring of the Neretva Delta (Croatia). Freshwater Crayfish, 12, 620-628.

GUAN R.Z., WILES P.R., 1998. Feeding ecology of the signal crayfish Pacifastacus leniusculus in a British lowland river. Aquaculture, 169, 177-193. 
HART D.D., 1992. Community organization in streams: the importance of species interactions, physical factors and chance. Oecologia, 91, 220-228.

HESSEN D.O., KRISTIANSEN G., SKURDAL J., 1993. Nutrient release from crayfish, and its potential impact on primary production in lakes. Freshwater Crayfish, 9, 311317.

HESSEN D.O., SKURDAL J., 1986. Analysis of food utilized by the crayfish Astacus astacus in Lake Steinsfjorden, S.E. Norway. Freshwater Crayfish, 6, 187-193

ILHÉU M., BERNARDO J.M., 1993. Experimental evaluation of food preferences of red swamp crayfish, Procambarus clarkii: vegetal versus animal. Freshwater Crayfish, 9, 359-364.

ILHÉU M., BERNARDO J.M., 1995. Trophic ecology of red swamp crayfish Procambarus clarkii (Girard): preferences and digestibility of plant foods. Freshwater Crayfish, 10, 132-139.

KELLER T.A., RUMAN L.C., 1998. Short-term crayfish effects on stream algae and invertebrates. J. Freshwat. Ecol., 13, 97-104.

LODGE D.M., KERSHNER M.W., ALOI J.E., COVICH A., 1994. Effects of an omnivorous crayfish (Orconectes rusticus) on a freshwater littoral food web. Ecology, 75, 12651281.

LOWE R.L., LALIBERTE G.D., 1996. Benthic stream algae: distribution and structure. In: HAUER F.R., LAMBERTI G.A. (Eds), Methods in stream ecology. Academic Press, San Diego, California, pp. 269-293.

LUTTENTON M.R., HORGAN M.J., LODGE D.M., 1998. Effects of three Orconectes crayfishes on epilithic microalgae: a laboratory experiment. Crustaceana, 71, 845855.

MARGALEF R., 1983. Limnología. Omega, Barcelona.

MATTHEWS W.A., REYNOLDS J.D., KEATING M.J., 1993. Macrophyte reduction and benthic community alteration by the crayfish Austropotamobius pallipes. Freshwater Crayfish, 9, 289-299.

NYSTRÖM P., 2002. Ecology. In: HOLDICH D.M. (Ed.), Biology of freshwater crayfish. Blackwell Science, Oxford, pp. 192-235.

NYSTRÖM P., ABJÖRNSSON K., 2000. Effects of fish chemical cues on the interactions between tadpoles and crayfish. Oikos, 88, 181-190.

NYSTRÖM P., BRÖNMARK C., GRANÉLI W., 1999. Influence of an exotic and a native crayfish species on a littoral benthic community. Oikos, 85, 545-553.

NYSTRÖM P., SVENSSON O., LARDNER B., BRÖNMARK C., GRANÉLI W., 2001. The influence of multiple introduced predators on a littoral pond community. Ecology, 82, 1023-1039.

O'BRIEN B.G., 1995. The natural diet of the freshwater crayfish Cherax tenuimanus (Smith 1912) (Decapoda: Parastacidae) as determined by gut content analysis. Freshwater Crayfish, 10, 151-162.

PERRY W.L., LODGE D.M., LAMBERTI G.A., 1997. Impact of crayfish predation on exotic zebra mussels and native invertebrates in a lake-outlet stream. Can. J. Fish. Aquat. Sci. , 54, 120-125.

RABENI, C.F., GOSSET M., McCLENDON D.D., 1995. Contribution of crayfish to benthic invertebrate production and trophic ecology of an Ozark stream. Freshwater Crayfish, 10, 163-173. 
REYNOLDS J., 1978. Crayfish ecology in Ireland. Freshwater Crayfish, 4, 215-220.

RIVAS R., ROMAIRE R., AVAULT J.W., GIAMALVA M., 1978. Agricultural forages and byproducts as feed for crawfish. Freshwater Crayfish, 4, 337-342.

ROMAIRE R.P., FORESTER J.S., AVAULT J.W., 1978. Growth and survival of stunted red swamp crayfish (Procambarus clarkii) in a feeding-stocking density experiment in pools. Freshwater Crayfish, 4, 331-336.

SAFFRAN K.A., BARTON D.R., 1993. Trophic ecology of Orconectes propinquus (Girard) in Georgian Bay (Ontario, Canada). Freshwater Crayfish, 9, 350-358.

SLATER F.M., RAYNER G., 1993. Austropotamobius pallipes in otter diet in the mid-Wye catchment of central Wales. Freshwater Crayfish, 9, 365-367.

STEINMAN A.D., LAMBERTI G.A., 1996. Biomass and pigments of benthic algae. In: HAUER F.R., LAMBERTI G.A. (Eds), Methods in stream ecology. Academic Press, San Diego, California, pp. 295-313.

TURNER A.M., BERNOT R.J., BOES C.M., 2000. Chemical cues modify species interactions: the ecological consequences of predator avoidance by freshwater snails. Oikos, 88, 148-158.

USIO N., TOWNSEND C.R., 2002. Functional significance of crayfish in stream food webs: roles of omnivory, substrate heterogeneity and sex. Oikos, 98, 512-522.

WARNER G.E., 1997. Factors affecting the selection of pond snail prey by signal crayfish. Freshwater Crayfish, 11, 194-202.

WARNER G.E., GREEN E.I., 1995. Choice and consumption of aquatic weeds by signal crayfish (Pacifastacus leniusculus). Freshwater Crayfish, 8, 360-363.

WARNER G.E., WOOD W.C., ORR-EWING, R.H., 1995. Signal crayfish (Pacifastacus leniusculus) feeding on pond snails: optimal foraging? Freshwater Crayfish, 8, 352359.

WEBER L.M., LODGE D.M., 1990. Periphytic food and predatory crayfish: relative roles in determining snail distribution. Oecologia, 82, 33-39.

WESTMAN K., SÄRKÄÄ J., PURSIAINEN M., SUMARI O., 1986. Population structure and gut contents of the crayfish Astacus astacus in two Finnish rivers. Freshwater Crayfish, 6, 166-177.

WHITLEDGE G.M., RABENI, C.F., 1997. Diel and seasonal variation in the food habits of crayfishes in a Missouri Ozark stream. Freshwater Crayfish, 11, 159-169. 
